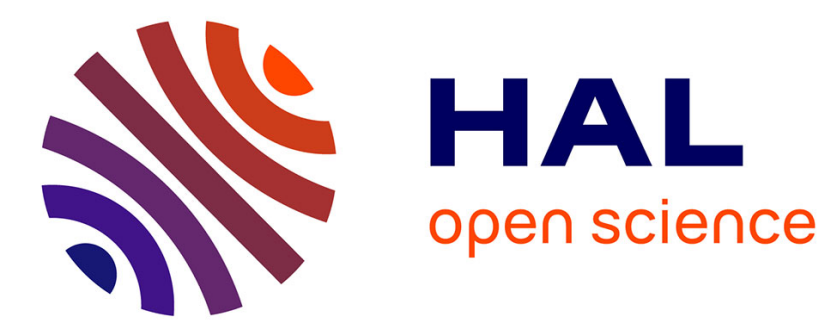

\title{
Relativization strategies and alignment in Thulung Rai
}

Aimée Lahaussois

\section{To cite this version:}

Aimée Lahaussois. Relativization strategies and alignment in Thulung Rai. Cahiers de linguistique Asie Orientale, 2017, 46 (1), pp.73 - 100. 10.1163/19606028-04601003 . hal-01657461

\section{HAL Id: hal-01657461 https://hal.science/hal-01657461}

Submitted on 14 Dec 2017

HAL is a multi-disciplinary open access archive for the deposit and dissemination of scientific research documents, whether they are published or not. The documents may come from teaching and research institutions in France or abroad, or from public or private research centers.
L'archive ouverte pluridisciplinaire HAL, est destinée au dépôt et à la diffusion de documents scientifiques de niveau recherche, publiés ou non, émanant des établissements d'enseignement et de recherche français ou étrangers, des laboratoires publics ou privés. 
Relativization strategies and alignment in Thulung Rai/Stratégies de relativisation et alignement en thulung rai

Aimée Lahaussois

\section{Abstract}

This article describes the relativization strategies found in Thulung Rai (Eastern Nepal, TibetoBurman, Kiranti subgroup). The strategies make use of three morphemes: a finite nominalizer $-m$ (along with allomorph - mim), and two participial markers, - pa and - ma, and have different distributions in terms of the arguments they can relativize upon. Of particular interest is the question of the distribution of strategies available for relativization on subjects, and how these correlate with case marking and the person-based split ergative system found in Thulung

Résumé

Cette article décrit les stratégies de relativisation trouvées en thulung rai (Népal oriental, tibétobirman, sous-groupe kiranti). Ces stratégies font appel à trois morphèmes distincts : un nominalisateur - $m$ (et son allomorphe - mim), ainsi que deux marqueurs participiaux, - pa et - ma, avec des distributions différentes selon les arguments sur lesquels porte la relativisation. Une question d'intérêt est celle de la distribution des stratégies pour la relativisation du sujet et de la corrélation de ces stratégies avec le marquage de cas du thulung, étant donné que le thulung est une langue avec un marquage ergatif scindé.

Keywords: relative clause, ergative language, alignment, accessibility hierarchy, relativization strategies

Mots clés : stratégies de relativisation, proposition relative, langue ergative, alignement, hiérachie d'accessibilité

Introduction

My goal in this article is to present the relativizing strategies used in Thulung Rai. There are three strategies available, but they each have different distributions based on the role of the head of the relative clause (henceforth $\mathrm{RC}$ ) in the matrix sentence.

Section 1 of this article provides an overview of the language. Section 2 presents the types of nominalization patterns found in Sino-Tibetan languages and how they manifest in Thulung. These patterns are relevant to the topic at hand because the three relativization strategies used in Thulung, nominalizer - $m$ and participial markers - $p a$ and - $m a$, also participate in other nominalizing functions. Section 3 presents generalities about relativization in Thulung. Section 4 discusses the relativization of core arguments $(\mathrm{S}, \mathrm{A}$ and $\mathrm{P})$ and the constraints on various strategies. Section 5 presents the relativization of non-core arguments: indirect objects, locative, instrumental, comitative, ablative/allative, and genitive. Section 6 presents the typological background against which the data should be examined, notably the accessibility hierarchy from Keenan and Comrie 1977 and the question of how Thulung's ergative split plays into patterns of relativization.

1. Overview of the language 
Thulung Rai is a Tibeto-Burman language of the Kiranti subgroup, spoken in Solu district in Eastern Nepal by several thousand speakers. It is an exclusively oral language which was the subject of descriptive work by Allen (1975).

From a typological point-of-view, Thulung is an extensively suffixing language with an ergative split, with 2nd person plural and 3rd person A arguments taking ergative case-marking, and human $\mathrm{P}$ arguments marked with -lai. $\mathrm{P}$ marking is optional on non-human animates and elsewhere (Lahaussois 2003a, 2003b). Thulung is also characterized by complex verbal morphology, with distinct sets of intransitive and transitive markers encoding person and number of up to two arguments (Lahaussois 2011).

\section{Standard Sino-Tibetan Nominalization pattern}

Thulung follows the same pattern found throughout the Sino-Tibetan area, with nominalizing morphology covering a number of functions. These patterns have been documented widely (Matisoff 1972, DeLancey 1989, Noonan 1997, Genetti et al 2008, Yap et al 2011, among others) and given the label Standard Sino-Tibetan Nominalization (SSTN), (Bickel 1999). The following varied functions have been found to share the same nominalizing morphology : attributive/genitive marking, relativization, nominalization both at the clausal and sentential levels. The Thulung morphemes which participate in SSTN are - $p a,-m a$, and $-m$, and the range of functions they each cover will be discussed in turn.

Cognates for Thulung - $p a$ and $-m$ in some other Kiranti languages were presented in Lahaussois 2003a. A few additional cognates are presented here, in an attempt to show that suffixes related to - $p a$ and - $m$ are found widely in languages geographically close to Thulung. Khaling has an active participial marker $-p \varepsilon$ and a nominalizer ${ }^{1}-m /-m i ̂ m$ (the latter is described in Jacques and Lahaussois 2014: 395-396). Kulung has an active participle in - pa/-p (Tolsma 2006: 120-123), as well as an infinitive marker - ma/-m (ibid 125-128) with some functions which overlap with those of Thulung - $m$ (see 2.3). Nothing akin to an unspecified nominalizer is described for Kulung. Dumi has an active participle - $k p \dot{t} /-p \dot{t}$ (van Driem 1993: 272-274), which is cognate with Thulung - $p a$, and a nominalizer $-m$ (ibid, 190-197).

\subsection{Main functions of the active participle marker - $p a$}

\subsubsection{Active participle marker}

The main function found for the morpheme -pa is as an active participial marker. This is exemplified in (1) through (3).

\begin{tabular}{llllcr} 
Iuy & ts $\Lambda i$ & tsjapljapkai & rwak-pa & \multicolumn{1}{c}{ kwa-je } & lus-ta \\
stone & CONTR & ONOM & call-ACT.PTCP & mud-low.LOC & come.out-PST
\end{tabular}

'The stone jumped down into the mud making a falling sound.'

$\begin{array}{lllll}\text { dhamu-la dipti } & \text { hopmam } & \text { wak-pa } & \text { Iwa-na } \\ \text { sky-ABL } & & \text { light like } & \text { burn-ACT.PTCP } & \text { see-2SG >3SG }\end{array}$

'Do you see the thing shining like a lamp in the sky?'
lodoro
tst-num bal-ta-sik-pa,
thorn.plant thorn-COM wind.around-AUX-REFL-ACT.PTCP
tiger $\begin{gathered}\text { gupst } \\ \text { over.there }\end{gathered}$

\footnotetext{
${ }^{1}$ It is interesting to note that the allomorphy is very close to that in Thulung, although note that Khaling -mîm has a tone.
} 


\author{
athjo gele dhali sokhli be-pa, homubhrepa hapa pe-pa, \\ over.here up downhunting do-ACT.PTCP bear lazy a.lot eat-ACT.PTCP \\ $\begin{array}{lclll}\text { nokst } & \text { prok-bal-pa } & \text { phal-bal-pa, } & \text { mini } & \text { sewari } \\ \text { monkey } & \text { jump-AUX-ACT.PTCP } & \text { destroy-AUX-ACT.PTCP } & \text { human } & \text { headdress }\end{array}$ \\ bha:-pa-ma kholelwa rep-bal-pa, irma mam-num bat-pa \\ ACT.PTCP \\ wear-ACT.PTCP-CONJ all story look-AUX-ACT.PTCPgirl.name mother-COM be- \\ dum-miri $\quad$ ?e \\ become-3PL.PST HS \\ 'They became the thorn wrapping around [trees] with its thorns, the tiger going this way and \\ that, up and down, hunting, the bear, acting lazy and eating a lot, the monkey, jumping around \\ and destroying things, Mini wearing a headdress and looking into everyone's business, Irma \\ staying with her mother.'
}

\title{
2.1.2 Complementizer
}

The morpheme - pa is also used in complementation, subordinating the clause it marks to the main verb of the sentence. This is seen in examples (4) and (5) which respectively use the main verbs 'to pretend' and 'to know', with the -pa marked clause functioning as a complement to the verbs ${ }^{2}$.

$\begin{array}{llll}{\left[\begin{array}{lll}\text { go } & \text { set- } d a & l \Lambda k-p a\end{array}\right]} & l i \text {-sa } \\ \text { fish } & \text { kill-PURP } & \text { go-ACT.PTCP } & \text { pretend-2SG.IMP } \\ \text { 'Pretend that you are going fishing.' } & \end{array}$

$$
\begin{aligned}
& \text { [u-ri-tsip bu-tsi rwak-pa] tha bu- } q u-m \text { phtshi } \\
& \text { 3POSS-sibling-DU be-3DU say-ACT.PTCP know do-3SG>3SG.PST-NMLZ after } \\
& \text { 'After she learned that he had two sisters.' }
\end{aligned}
$$

2.2 Main functions of the passive participle marker - ma

\subsubsection{Passive participle marker}

The main function of - mais to form passive participles, as seen in (6).
(6) ckamke khok-dzol-ma, nem wo sjay-dzol-ma, baetshim-ma, food cook-put-PASS.PTCP house also clean-put-PASS.PTCP floor sweep- PASS.PTCP
dus-thal-la ?e
become-AUX-PST HS
'the cooked meal, the cleaned house, the swept floor were ready.'

\subsubsection{Nominalization of comitative-marked NPs}

A very wide-spread use of - ma is to nominalize comitative-marked nouns, describing a characteristic of the noun in question. This is illustrated in (7) and (8).

\footnotetext{
${ }^{2}$ Japhug Gyalrong also uses the S/A (ie. active) participle to form complements for verbs of pretence (Jacques, to appear).
} 
jum-num-ma

power-COM-PASS.PTCP

'the one with power'

\subsection{Main functions of nominalizer $-m$}

The morpheme $-m$ is best described as the standard nominalizer in Thulung, as it is used for a wide range of nominalizations. It undergoes allomorphy conditioned by tense: - $m$ is used with past forms, and allomorph -mim with non-past forms. ${ }^{3}$

\subsubsection{Expression of perfect aspect}

Perfect aspect is expressed through a construction with an - $m$ nominalized verb and copula. This is shown in (9) and (10).

$$
\begin{aligned}
& \text { meram leledtm-mim-ka } \quad \text { dul-miri-m } \\
& \text { DEM boogeyman-PLU-ERG care.for-3PL.PST-NMLZ be-PST HS } \\
& \text { 'Those boogeyman had cared for them.' }
\end{aligned}
$$

bwa dzam-ra Ins-ta-m $\quad b u$
pig feed-PURP go-PST-NMLZ be
'She has gone to feed the pig.'

\subsubsection{Standard nominalizations}

The nominalizer - $m$ is used for the nominalization of entire sentences (11), of clauses (12), as well as for complementation (13), to mark attribution (14), (15), and for verbal nominalization $^{4}(16$.

(11) [homu-kubwi theptso dus-ta-m] ?e bear-GEN head flat become-3SG.PST-NMLZ HS '(It is said that) the bear's head became flat.'

(12) [suk-khep dzes-i-mim] tsıyra three-times speak-1PI-NMLZ after 'After we say it three times...'

(13) [bhansa go khok-to-m] rwak-ta food 1SG cook-1SG>3SG.PST-NMLZ say-PST 'I cooked the food, she said.'

\footnotetext{
3 The conditioning is in fact a little more complicated than simply tense, as it also takes into account syllable length of the marked verb. Non-past verbs which are bisyllabic or more can be nominalized with either - $m$ or -mim, whereas past verbs, which are always at least bisyllabic, can only be nominalized with $-m$.

${ }^{4}$ Note that the infinitive form of verbs is formed in - $m u$ and not in $-m$.
} 
oram bhante- $m^{5}$

this where-NMLZ

'This one from somewhere we don't know.' [lit. this where's]

\begin{tabular}{llll} 
baja-ra-m khole & $k u-k u$ & \multicolumn{1}{c}{ mam } \\
earth-LOC-NMLZ & all water-GEN mother \\
'all the springs of the earth' & &
\end{tabular}

$\begin{array}{llll}\text { pi-mim } & \text { re } & o & n e \\ \text { eat-NMLZ } & \text { FOC } & \text { this } & \text { TOP } \\ \text { 'This is to eat.' } & & & \end{array}$

\section{Relativization}

In addition to the functions described in section 2, the morphemes - $p a$, - $m a$ and - $m$ all participate in relativization in Thulung.

While some languages from the same family and from the Kiranti subgroup have a number of options for the structure of RC's-internally- or externally-headed, pre- or post-nominal (Genetti et al 2008: 128, Bickel 1995) - this is not the case for Thulung. No matter which relativizing morpheme is used, Thulung relatives are always prenominal and externally headed, as can be seen in (17), where the relative clause (bracketed) precedes the head noun dzam.

$\begin{array}{llll}\text { [go } & \text { khok-to-m] dzam } & \text { brspa } & \text { ba-ida } \\ \text { 1SG } & \text { cook-1SG>3SG.PST-NMLZ } & \text { rice good be-PST }\end{array}$

'The food I cooked was good.'

Headless relative clauses are also common, such as (18), where the head noun (which could be mutsu, 'person') is omitted from the matrix clause.
[ama tsape qupe be-pa,
dukhs
be-pa]
rok-a
1 POSS food drink make-ACT.PTCP hardship
do-ACT.PTCP
come-2SG.IMP
'Come, person who makes my food, who works hard!'

Unlike what has been described for a number of languages (Dixon 2009:341, Yap et al 2011), Thulung does not appear to have restrictions on tense/aspect in RC's. When the relativization strategy is to use the nominalizer - $m$, the result is a fully finite $\mathrm{RC}$, with the same person/number and TAM markers on the verb of the relative clause as would appear in an independent clause.

\section{Relativization on core arguments (S, A, P)}

Depending on the argument which is relativized upon in a sentence, different strategies will apply, with different distributions of the relativizers - $p a,-m a$ and $-m$.

\subsection{Relativization on S}

When the head noun is the $S$ of the relative clause, the most frequently found strategy is the use the active participial marker - $p a$. The nominalizer - $m$ can also be used, but with restrictions. The participial relative clause in - pa, being non-finite, has no tense marking morphology. Arguments

\footnotetext{
${ }^{5}$ Note that Thulung has a genitive marker $-k u$, as seen in examples (10) and (14).
} 
must be clearly identifiable, as verb morphology cannot be used to identify the arguments. The usual interpretation of the relative clause is as non-past, but interpretation as past is possible if called for by the context (see (21) and (22)).

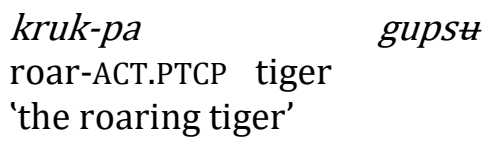

$\begin{array}{ll}\text { on-pa } & \text { mutst } \\ \text { run-ACT.PTCP person } & \\ \text { 'the running person' }\end{array}$

malo ghk-pa tsetstse

just be.born-ACT.PTCP child

'the just-born child'

$\begin{array}{lll}\text { mam-ku } & \text { si-pa } & \text { rem } \\ \text { mother-GEN } & \text { die-ACT.PTCP } & \text { body } \\ \text { 'mother's dead body' } & \end{array}$

The other available strategy involves using the standard nominalizing morpheme $-m$. Because this strategy results in finite relative clauses, the resulting clauses code for tense, as seen in (23).

$$
\begin{aligned}
& \text { kruk-ta-m gupst } \\
& \text { roar-PST-NMLz tiger } \\
& \text { 'the tiger that roared' }
\end{aligned}
$$

The possibility of forming non-past equivalents is restricted: the reading of non-past forms is, in the absence of aspectual markers, generic. Note that the non-relative sentences equivalent to the ungrammatical relative clauses without aspectual marking (such as habitual, continuous, or progressive) are also considered odd.

$$
\begin{array}{ll}
\text { *krur-mim } & \text { gupst } \\
\text { roar-NMLZ } & \text { tiger }
\end{array}
$$

[intended:] 'the tiger that roars'

With added aspectual morphology ${ }^{6}$, however, relativized non-past forms become acceptable.

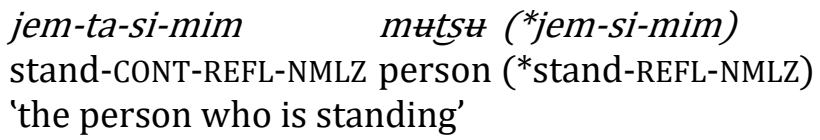

With stative verbs, on the other hand, the non-past form can be relativized, as in (26).

$$
\begin{array}{ll}
\text { me-Iwasi-mim } & \text { gupst } \\
\text { NEG-be.visible-NMLZ } & \text { tiger }
\end{array}
$$

${ }^{6}$ Note that the morpheme - $\operatorname{ta}$ in (25) is a continuous marker, and completely unrelated to the - $t a$ in (23) which is an allomorph of the past marker $-d a$. 
'the invisible tiger'

In sum, there are two possible strategies for relativization on an S argument: The most common in narrative is with - $p a$, resulting in a non-finite relative clause which usually has a nonpast reading. The less common, but still perfectly grammatical strategy, is to relativize with $-m, a$ strategy mostly found with past relative clauses.

\subsection{Relativization on $\mathrm{A}$}

When the head noun is the A argument of the relativized clause, there is a single relativization strategy available: the use of - pa. Because of the non-finite nature of participles, tense is not coded in these relatives.

As with relativization on $\mathrm{S}$, the usual interpretation is non-past.

$\begin{array}{llll}{[\text { make-m } m} & \text { semdilwa } & \text { se-pa] } & \text { mutst } \\ \text { long.ago-NMLZ } & \text { story } & \text { tell-ACT.PTCP } & \text { person }\end{array}$

'the person telling an old story'

marke khli-pa mutst

grain plant-ACT.PTCP human

'the person planting grains'

Relativization on a pronominal head noun acting as $\mathrm{A}$ is possible:

$\begin{array}{lllll}\text { ma:ke } & \text { khli-pa } & \text { gana-lai } & \text { go } & \text { Iwa-nni } \\ \text { grain } & \text { plant-ACT.PTCP } & \text { 2SG-DAT } & \text { 1SG } & \text { see-1SG>2SG.PST }\end{array}$

'I saw you planting grains.'

$\begin{array}{lccc}\text { make-m } m & \text { semdilwa } s \theta-p a & g o \\ \text { long.ago-NMLZ story } & \text { tell-ACT.PTCP } & \text { 1SG } & \\ \text { 'I, who tell an old story, ...' } & & & \end{array}$

A past reading will result from the use of temporal adverbs which fix the RC as past (31), or from the context of the matrix clause (32):

\begin{tabular}{|c|c|c|c|}
\hline $\begin{array}{l}\text { make } \\
\text { long.ago }\end{array}$ & $\begin{array}{l}\text { ts } \theta \text { ts } \operatorname{se} \theta-l o \\
\text { child-TEMP }\end{array}$ & $\begin{array}{l}\text { gupsy } \\
\text { tiger }\end{array}$ & I Iwa- \\
\hline
\end{tabular}

'the woman who saw a tiger when she was a child'

meramnem bınebe-pa mutsu si-da

DEM house make-ACT.PTCP person die-3SG.PST

'The person who built that house is dead.'

Any attempt to produce a nominalized finite equivalent for an RC on a A role is rejected, or, alternately, corrected by turning it into a complement clause. Complement clauses, while they look similar to finite RC's, do not gap the head noun in the clause. This is a crucial syntactic test in 
distinguishing between pre-head RC's (the only type found in Thulung) and various types of nominalizations which share the same morphology. ${ }^{7}$

\begin{tabular}{|c|c|c|c|}
\hline [meram & $m u t s t-k a$ & ma:ke khli-ju-mim] & go la-u \\
\hline
\end{tabular}

While it is sometimes unclear whether one has a headless relative clause or a complement clause, the verbal agreement markers can provide a clue. In determining whether it is possible to relativize in - $m$ on a head noun made up of the pronoun gana ('2SG'), I was given sentences (34) and (35):

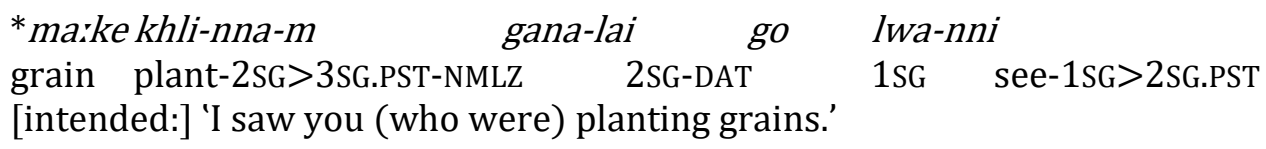

\begin{tabular}{|c|c|c|c|c|}
\hline gana & maike & khli-nna-m & la-uto & \\
\hline & grain & plant -2SG > 3SG.PST-NMLZ & $1 \mathrm{SG}$ & see-1SG $>3$ SG.PST \\
\hline
\end{tabular}

While (35) could plausibly have been a relative clause with the head noun preposed, the agreement marking on the matrix clause verb reveals that it is a complement clause: the 1SG $>$ 3SG marker indicates that the $\mathrm{P}$ is a 3SG, namely the clause [you plant grains]; if gana marke khli-nna-m in (35) had been a RC, the agreement marking on the matrix verb would have been $1 \mathrm{SG}>2 \mathrm{SG}$, as $2 \mathrm{SG}$ would have been the P.

Relativization on an A argument is thus only possible with a single strategy: participial relativization with - $p a$; the tense is non-past by default, unless context makes it otherwise; the RC is necessarily non-finite.

\subsection{Relativization on $\mathrm{P}$}

When the head noun is the $\mathrm{P}$ argument of the relative clause, the two possible strategies are to use the standard nominalizer $-m$ and the passive participial marker, $-m a$. Relativizing with $-m$ results in a fully finite clause, which can optionally include agents, as in (36), but need not, as in (37).

[khomda-ka bt- $q u-m] \quad$ kaijo thakro
Khomda-ERG do-3SG>3SG.PST-NMLZ comb brush
'the comb and brush which Khomda made'

pt-mim dzam
eat-NMLZ food
'the food (he) eats'

The other commonly available strategy is relativization with the passive participial marker ma.

$$
\text { athambili wo tsa-mma se pi-ji-lo jo lt-pa }
$$

7 The fact that (33) cannot be translated "I see the grains that that person is planting" also shows us that Thulung does not have internally-headed RC's. 
nowadays also roast-PASS.PTCPmeat eat-1PI>3SG-TEMP salt taste-ACT.PTCP 'Even now when we eat roasted meat, it tastes salty.'

\section{yado khli-mma maike-mim tho:-mi}

earlier plant-PASS.PTCP grain-PL be.ready.for.harvest-3PL

'The grains planted earlier are ready for harvest.'

There is however a constraint on its use: it cannot co-occur with an agent in the RC (see (41)).

Iwa-mma mutst
see-PASS.PTCP person
'the seen person'

but

(41) *go lwa-mma mutst

1SG see-PASS.PTCP person

[intended:] 'the person seen by me'

Interestingly, the active participle marker - pa can be be found with two instances of P relativization, both found with great frequency but limited to these two scenarios. Even though the use of - pa for relativization here is very unusual, the fact that the non-animate nature of the head noun forces the only possible interpretation as a $\mathrm{P}$. The frequency of their use suggests that these expressions can be thought of as lexicalized. Also noteworthy is that they have equivalents in Nepali-khāne kurā (eatNPST.PTCP thing, 'food') and bhan-eko kurā (say-PST.PTCP thing, 'the thing talked about'), and it is likely that these expressions are calqued.

(42) pe-pa dzam/thok

eat-ACT.PTCP food/thing

'food for eating'

(43) rwak-pa lwa

say-ACT.PTCP story

'the thing that was said'

\section{Relativization on non-core arguments}

In this section, I discuss the arguments other than $\mathrm{S}, \mathrm{A}$ and $\mathrm{P}$ which are potentially accessible to relativization. Indirect objects deserve special treatment as we must consider the accessibility to relativization of two roles, namely $\mathrm{G}$ and $\mathrm{T}$, and the strategies that allow such relativization.

The adjunct categories which will be discussed are locative, instrumental, comitative, ablative/allative, genitive. Objects of comparison, which can be relativized upon in some languages, are inaccessible in Thulung. The general rule concerning relativization on adjuncts is that all three strategies are usually possible: finite relativization with - $m$ is always possible. Relativization with $p a$ is usually possible, with a generic reading or a non-past reading concerning a specific event, and the agent can appear in this type of relative clause; however, relativization with - pa is blocked in situations where the interpretation defaults to an $\mathrm{A}$ or an $\mathrm{S}$ role for the head noun: this happens with all comitatives and with genitives where the verb in the relative clause is transitive. Relativization with - ma is usually possible, with a past reading, but is blocked for relative clauses where the head-noun is a genitive modifier in the relative (5.6). 


\subsection{Indirect object}

While we find 'indirect object' as a single slot on the accessibility hierarchy presented in Keenan \& Comrie (1977), it is in fact necessary to look into the relativization possibilities for the two non-A arguments of ditransitive verbs, especially insofar as not all verbs treat these arguments in the same way with respect to verb agreement.

To give the reader a general sense of what a ditransitive construction looks like in Thulung, consider (44).

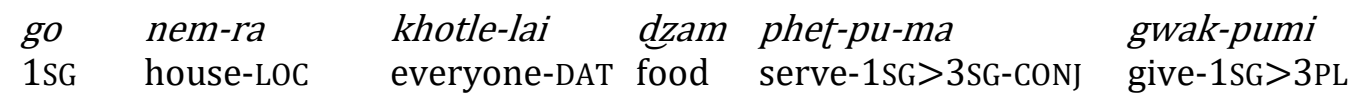

'At the house, I serve food to everyone and give it to them.'

The A is $g o$, ' $1 \mathrm{SG}^{\prime}$, which is unmarked for case as it is in the nominative (Thulung has a split ergative, with 2PL and 3rd person A's marked for ergative, while 1st person and 2SG and 2DU are in the nominative case, see Lahaussois 2003b). The G (the most goal-like argument) in (44) is khotle, 'everyone'. The dative marking it receives is borrowed from Nepali and serves to mark primary objects: both P's and G's when these are human (and sometimes particularly salient non-human animates). The T (the other most patient-like argument) in (44) is dzam, 'food', which is unmarked for case.

One noteworthy issue is that the marking is the same regardless of the type of ditransitive verb. If we consider again (44), we see that there are two ditransitive verbs present, and yet they show different verb agreement. The first verb, phenmu 'serve', takes dzam 'food' as its patient (as indicated by the 1SG>3SG marker - $p u$ ), whereas the second verb, gwa:mu 'give', indexes a 3PL patient concordant with khotle 'everyone', these two types of verbs corresponding to what have been called indirective and secundative respectively (Malchukov et al 2010: 3). This contrast in the two types of agreement marking stands in opposition to the case marking, which always assigns dative -lai to $\mathrm{G}$ and leaves $\mathrm{T}$ unmarked, regardless of the type of ditransitive verb. In this sense, Thulung is different from some related languages, such as Chintang and Belhare, which not only have different agreement marking but also different types of alignment depending on the class of ditransitive verb (Bickel et al, 2010). That said, even with the agreement and case marking diversity found within the ditransitive verbs of Chintang and Belhare, the latter languages show no constraints on relativization, both $\mathrm{T}$ and $\mathrm{G}$ being accessible to relativization using the same strategy.

As for Thulung, of the three available relativization strategies, two of them can be used to relativize on both $\mathrm{G}$ and $\mathrm{T}$. Examples (45)-(48) show that relativization on $\mathrm{G}$ can be achieved using -m ((45) and (47)), for a finite RC, and -ma ((46) and (48)), for a non-finite RC from which the A argument is removed.

$\begin{array}{lll}\text { gana dzam gwak-nami-m } & \text { mutst } \\ \text { 2SG food give-2SG }>3 \text { PL-NMLZ } & \text { person } \\ \text { 'the people you gave food to' } & \end{array}$

(note 2SG > 3PL marking on verb, and no indexing of dzam 'food')

dzam gwak-ma mutst

food give-PASS.PTCP person

'the person food was given to'

$\begin{array}{llrl}\text { go } & \text { khuluy } & \text { sok-to-m } & \text { mutst-mim } \\ \text { 1SG money } & \text { pay-1SG }>\text { 3SG.PST-NMLZ } & \text { person-PL } \\ \text { 'the people I paid money to' } & \end{array}$

(note 1SG>3SG marking on verb, indexing 'money' as P, not 'people') 
'The people who were paid money'

Relativization on T is also achieved using the same two strategies: (49) and (51) show relativization using - $m$ resulting in finite RC's, while (50) and (52) show relativization using - $m a$, resulting in non-finite clauses from which the A must be omitted.

$\begin{array}{lll}\text { khotle-lai gwak-tomi-m dzam } & \text { gwa } \\ \text { everyone-DAT } & \text { give-1SG>3PL.PST-NMLz } & \\ \text { 'The food that I gave to everyone' } & \end{array}$

(50) khotle-lai gwak-ma dzam everyone-DAT give-PASS.PTCP food

'The food given to everyone'
khotle-lai sok-to-m khsulup
everyone-DAT pay-1SG>3SG.PST-NMLZmoney
'The money I paid to everyone'
khotle-lai sok-ma khıuluy
everyone-DAT pay-PASS.PTCP money
'The money paid to everyone'

Relativization with - paleads to a different interpretation when the head noun is the $\mathrm{G}$ argument: the RC is interpreted as having an A head noun, rather than a G head noun, as in (53). Because relativization with participials necessarily blocks the A from appearing inside the RC, it is not possible to force three arguments into a clause such as (48). As a result, the reading of the head noun of the RC is as the A of a G-less ditransitive verb.
dzam gwak-pa mutst
meal give-ACT.PTCP person
*the person rice was given to
'the person who gave rice'

When - pa is used in an attempt to relativize on $\mathrm{T}$, there is no interpretation that makes sense.

$$
\begin{array}{lll}
* \text { khotle-lai } & \text { gwak-pa } & \text { dzam } \\
\text { everyone-DAT } & \text { give-ACT.PTCP food } \\
\text { [intended:] 'the rice given to everyone' }
\end{array}
$$

Because relativization in - pa is the exclusive strategy for A relativization, and the head noun in (54) cannot be an A (being non-animate), there is no possible way to resolve the RC.

The two possible strategies for both $\mathrm{G}$ and $\mathrm{T}$ are therefore $-m$ and $-m a$. Thulung has primary object marking for case, with both (human) P and G taking the same marking (dative -lai), and both (non-human) $\mathrm{P}$ and $\mathrm{T}$ taking the case (remaining unmarked). The relativization strategies available for $\mathrm{P}$ (both human and non-human) are the same as those found for $\mathrm{G}$ and for $\mathrm{T}$.

\subsection{Locative}


For a head noun which would be locative case-marked if the relative clause were a main clause, all three relativization strategies are possible.

For adjunct relativization, the difference between the active and passive participle strategies seems to be neutralized to a matter of tense, with - pa coding non-past events (as in (55) and (56)) and - ma coding past events (as in (57) and (58)). Relativization with - $m$ being finite, tense is coded through verb agreement markers ((59), (60)).

$$
\begin{array}{lll}
\text { go } & \text { bat-pa } & \text { nem } \\
\text { 1SG } & \text { live-ACT.PTCP } & \text { house }
\end{array}
$$

'the house I live in'

go bhramu phot-pa je
1SG buckwheat sow-ACT.PTCP field
'the field I will plant buckwheat in'

$$
\begin{aligned}
& \text { je dzul-ma dzul-khop } \\
& \text { clothes place-PASS.PTCP put-place }
\end{aligned}
$$

$\begin{array}{ll}\text { tssettse-mim } & \text { sissit-ma iskul } \\ \text { child-PL } & \text { learn-PASS.PTCP }\end{array}$

'the school where the children studied (but don't study anymore as they are grown)'

$\begin{array}{lll}\text { go } & \text { bu- } \text { - } u \text {-mim } & \text { nem } \\ \text { 1SG } & \text { live-1SG-NMLZ } & \text { house }\end{array}$

'the house I live in'

go bopsesidzul-to- $m$ thal
1SG fruit place-1SG $>3$ SG.PST-NMLZ plate
'the plate I put fruit on'

For all of the relatives in the examples above it is possible to make the equivalent independent sentences in which the head noun from the RC becomes an adjunct with locative marking - ra.

\subsection{Instrumental}

When the head noun is an instrumental, all three strategies can be used. One of the challenges is that as the case marker is missing, some of the relative clauses below could potentially be on a locative rather than instrumental role (see for example (68), which is to be read as instrumental but could potentially have been interpreted as a locative). The examples must be checked against their case-marked independent sentence equivalents in order to ensure that the role is indeed an instrumental taking marker $-k a$.

Note that the main difference between active and passive participial strategies is one of tense: non-past for the former (see (61)), past for the latter ((62)-(64)) but that encoding of the agent remains, as with core arguments, blocked for - ma relative clauses. Finite relative clauses with - $m$ can contain not only explicit agents but also indication of the person and number of agent and patient via the agreement marking on the verb ((65)-(68)).

$$
\text { khadzem-ra rjak-pa rja:khop }
$$


book-LOC write-ACT.PTCP pen

'the pen (which will be) used to write in a book'

(62)

$\begin{array}{lll}\text { khadzem-ra } & \text { rjak-ma } & \text { rjakhop } \\ \text { book-LOC } & \text { write-PASS.PTCP } & \text { pen }\end{array}$

'the pen (which was) used to write in a book'

(63)

daksa phal-ma betho

tree cut-PASS.PTCP machete

'the knife (which was) used to cut the tree'

(64) khlea jal-ma dulumtsa

dog strike-PASS.PTCP stick

'the stick used to hit the dog'

tssettse-ka khlea jal-lu-m

'the stick the child beat the dog with'

go diksa phal-to-m betho

1SG tree cut-1SG>3SG.PST-NMLZ machete

'the machete I used to cut the tree'

khadzem-ra rjak-to-m rjakkop

book-LOC write-1SG>3SG.PST-NMLZ pen

'the pen I wrote in a book with'

$\begin{array}{lll}\text { go dzam } & \text { phet-pu-mim } & \text { thal } \\ \text { 1SG rice } & \text { serve-1SG }>3 \text { SG-NMLZ } & \text { plate } \\ \text { 'the plate I use to serve rice' } & \end{array}$

\subsection{Comitative}

When a comitative marker is used, the agreement on the verb indexes the number of the combination of comitative-marked argument and its companion. Verb agreement for the relevant arguments must therefore be at least dual when a comitative-marked element is present among arguments indexed on the verb. In (69), for example, the result is that agreement marker indexing the $\mathrm{A}$ is dual in number.

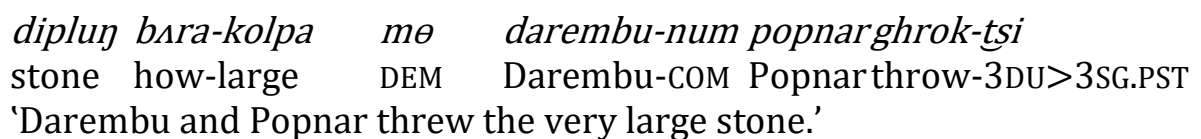

Given this pattern, finite clauses relativized with - $m$ will have non-singular verbs when they include a comitative-marked argument, even if the head noun of the RC is only the formerly comitativemarked argument (and does not include the other member of the NP, to which it was conjoined with comitative marking). This can be seen in (70)-(72).

(70) khojo khari be-ttsoko-m mutst always work do-1DE.PST-NMLZ person 
'the person I always work with (and who always works with me)' (lit. the we always work together person)

(71) tsamsit-tsi-m nopse

play-2DU-NMLZ friend

'the friend you played with (and who played with you)' (lit. the we played together friend)

(72) kathmandu-ra lamdit-tsoko-m nopse

Kathmandu-loc walk-1pe.pst-nmlz friend

'the friend I walked to Kathmandu with' (lit. the we walked to Kathmandu friend)

Relativization in - ma is also possible, as with other oblique arguments, resulting in an interpretation as a past and completed event, as in (73). Because of the non-finite nature of participial clauses, the verb does not have the non-singular agreement seen in (70)-(72).

tsamsit-ma nopse

play-pass.ptcp friend

'the friend I played with'

It is not possible to relativize upon the comitative-marked argument with - $p a$. The interpretation of any such RC will be as one with a head noun which is the A (74) or S (75).

(74) hellolo khari be-pa mutst

everyday work do-ACT.PTCP person

*the person we work with every day

'the person who works every day'

(75) tsamsit-pa nopse

play-ACT.PTCP friend

*the friend I play with

'the friend who is playing'

5.5 Ablative/allative

Thulung has a case marker for the ablative, -lanka (or variant-lam) (76), but the allative is unmarked and inferred from the context (77).

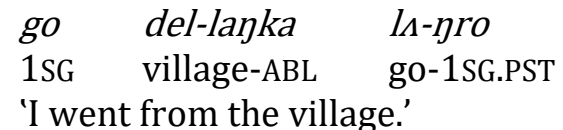

$$
\begin{aligned}
& \text { go del lh-pro } \\
& \text { 1SG village go-1SG.PST }
\end{aligned}
$$

'I went to the village.'

While all three relativization strategies are found with ablative/allative head nouns, there is a considerable amount of ambiguity concerning their relativization: as the case marker disappears in the process of relativization, it is not clear whether one has an ablative or allative head noun. With some verbs, the case is clear from the context. In (78) below, it is difficult to imagine plausible context for fetching water to a pond, and thus the ablative interpretation is the only realistic option; similarly in (79), the only plausible context 
for the relative is that the head noun is the tree that the person is dropped from, thus with an ablative interpretation. Note that in the following examples, $-m$ relativization is shown, but in each case, - $m a$ or - $p a$ relativization could have been substituted (after making necessary changes, such as removing the agent for ma relatives).

$$
\begin{array}{lll}
\text { gui ku h } \quad h \wedge r-i-m & \text { kudin } \\
\text { 1PI water } & \text { fetch.water-1PI-NMLZ } & \text { pond } \\
\text { 'the pond we fetched water from' } &
\end{array}
$$

$\begin{array}{lll}\text { gu-ka mutst-lai al-ly-m } & d \Lambda k s a \\ \text { 3SG-ERG person-DAT make.fall-3SG>3SG.PST-NMLZ } & \text { tree } \\ \text { 'the tree he made him fall from' } & \end{array}$

With directional motion verbs, which incorporate the direction of movement (go up, come down, carry away...), the most common interpretation appears to be the allative. Transitive directional verbs in the past have both interpretations-allative and ablative-equally available (see (81), (85)), while for intransitives, particularly in the non-past, the allative alone is possible (see (80), (83)). These patterns applied to all three relativization strategies (with the active and passive participial markers indexing nonpast and past respectively). Context plays an important part in the interpretation as allative or ablative, rather than any formal trait: a non-past directional verb, where the action is either in progress or in the future, will quite logically focus on the goal of that motion, rather than its source.

$\begin{array}{lll}\text { go } & \text { jo- } \text {-ro-m } & \text { khom } \\ \text { 1SG } & \text { come.down-1SG.PST-NMLZ place }\end{array}$

'the place that I came down to'

$$
\begin{array}{lll}
\text { go bolıkpu } \quad \text { khet-pu-mim } & \text { del } \\
\text { 1SG potato bring.up-1SG>3SG-NMLZ } & \text { village } \\
\text { 'the village I am bringing potatoes up to' } &
\end{array}
$$

$$
\begin{array}{lll}
\text { go } & \text { bılıkpu } \quad \text { khet-to-m } & \text { del } \\
\text { 1SG potato bring.up-1SG }>\text { 3SG.PST-NMLZ village }
\end{array}
$$

'the village I brought potatoes up to/from'

$$
\begin{aligned}
& \text { go bik-pa del } \\
& \text { 1SG come-ACT.PTPC village } \\
& \text { 'the village I am coming to' }
\end{aligned}
$$

(84) bik-ma del come-PASS.PTCP village

'the village I came to'

$$
\begin{aligned}
& \text { bılıkpu lık-ma del } \\
& \text { potato take-PASS.PTCP } \\
& \text { 'the village I am taking potatoes to/from' }
\end{aligned}
$$

\subsection{Possessive}


For a possessive-marked argument, only relativization with - $m((86)$ and (87)) and - pa (88) is available. Furthermore, there are additional constraints when the verb is transitive (89): only $-m$ can be used then, as the finite nature of the verb makes clear the argument structure; relativization in - pa would lead to the head noun being interpreted as an agent, as in (90).

$\begin{array}{lll}\text { wotsy } & \text { si-da-m } & \text { mersem } \\ \text { husband } & \text { die-3SG.PST-NMLZ woman }\end{array}$

'the woman whose husband died'

\section{malo nem dzhar-pa mutst}

just house fall.apart-ACT.PTCP person

'the person whose house fell apart recently' (lit. the just fallen.apart-house person)

$$
\text { go dzam thak-sat-to-m yopse }
$$

1SG food hide-BEN-1SG>3SG.PST-NMLZ friend

'the friend whose food I hid'

$$
\begin{aligned}
& \text { dzam thık-pa popse } \\
& \text { food hide-ACT.PTCP friend } \\
& \text { *the friend whose food is hidden } \\
& \text { 'the friend hiding food' }
\end{aligned}
$$

\begin{tabular}{|c|c|c|c|c|c|c|}
\hline -pa & $\begin{array}{c}\text { No } \\
\text { (interp. as } \\
\text { A) }\end{array}$ & Yes & Yes & $\begin{array}{c}\text { No } \\
\text { (interp. as A) }\end{array}$ & Yes & $\begin{array}{c}\text { Yes } \\
\text { (only for } \\
\text { vi) }\end{array}$ \\
\hline -ma & $\begin{array}{c}\text { Yes } \\
\text { (for both } \mathrm{G} \\
\text { and } \mathrm{T} \\
\text { arguments) }\end{array}$ & Yes & Yes & No & Yes & No \\
\hline
\end{tabular}

Table 1 sums up the possible relativization strategies for the non-core arguments discussed in section 5 .

Table 1. Relativization strategies available for non-core arguments

Suffix Indirect $\begin{gathered}\text { Object } \\ \text { Locative Instrumental Comitative Ablative/allative Possessive }\end{gathered}$ 


\begin{tabular}{|c|c|c|c|c|c|c|}
\hline $\begin{array}{l}-\mathrm{m} /- \\
\mathrm{mim}\end{array}$ & $\begin{array}{c}\text { Yes } \\
\text { (for both } \mathrm{G} \\
\text { and } \mathrm{T} \\
\text { arguments) }\end{array}$ & Yes & Yes & Yes & Yes & Yes \\
\hline
\end{tabular}

Relativization with the standard nominalizer $-m$ is clearly the strategy which is most widely available to non-core arguments, without any constraints. As mentioned in the individual subsections, one of the main factors constraining the use of participial relativizers for non-core arguments is that they result in interpretations which pick up a core argument: by virtue of their non-finiteness and the unavailability of agreement markers, participial relativizers make it impossible to disambiguate roles, and when there is a possibility of interpreting the head noun as the A, this strategy is not available.

\section{Typological issues}

The data presented above is interesting to consider with respect to typological research into relative clauses and their structure, most notably Keenan \& Comrie's (1977) accessibility hierarchy. Even though the accessibility hierarchy has been refined since (Lehmann 1986, Fox 1987), it remains a very useful tool, especially for a language with multiple relativization strategies which reveal different alignments. It is mentioned in nearly all discussions of relativization, sometimes as the main bibliographical reference (see for example Whaley 2010: 472), suggesting that, despite its nearly 40-year history, it is foundational to any description of relativization strategies, providing very useful insights. To sum up the well-known theory, Keenan and Comrie propose that arguments which are accessible to relativization in a given language will respect the following hierarchy:

$$
\text { subject }>\text { direct object }>\text { indirect object }>\text { oblique }>\text { genitive }>\text { object of comparison }
$$

The primary relativization strategy of a language will start at the top of the hierarchy, and go partway or all the way down, in a continuous segment, depending on the language. If we look at the three strategies described for Thulung, they are available for relativization on different arguments (relabeled to correspond to the discussion in the relevant sections above) as per table 2:

Table 2. Overview of relativization strategies for all arguments

\begin{tabular}{|c|c|c|c|c|c|c|c|}
\hline Suffix & S & A & $\mathrm{P}$ & $\mathrm{G} / \mathrm{T}$ & Obl & Gen & Obj Comp \\
\hline -pa & $\checkmark$ & $\checkmark$ & & & $\begin{array}{c}\text { mostly yes } \\
\text { (depends } \\
\text { on type) }\end{array}$ & $\begin{array}{l}\checkmark \text { (with } \\
\text { restrictions) }\end{array}$ & \\
\hline -ma & & & $\checkmark$ & $\checkmark$ & $\begin{array}{c}\text { mostly yes } \\
\text { (depends } \\
\text { on type) }\end{array}$ & & \\
\hline
\end{tabular}




$-\mathrm{m} /-\operatorname{mim} \quad \checkmark \quad \checkmark s$

Table 2 raises a number of issues in terms of the applicability of the accessibility hierarchy to Thulung.

The first point to note is that none of the strategies have a continuous run on the different positions accessible to relativization. Of the two strategies that can relativize on $\mathrm{S}(-p a$ and $-m)$ - and according to Keenan and Comrie (1977), relativization on $S$ is a requirement for determining the primary relativization strategy of a language - - pa does not cover $\mathrm{P}$ or $\mathrm{G} / \mathrm{T}$; $-m$ does not cover $\mathrm{A}$.

A great many linguists have mentioned the constraint on relativization in ergative languages. Among them, Creissels (2006: 215) notes that "dans les langues à alignement ergatif, il peut arriver que le sujet des constructions transitives ne soit pas relativisable". 8 The accessibility hierarchy has been reworked to allow for strategies relativizing on $\mathrm{S}$ and $\mathrm{A}$, on the one hand, and $\mathrm{S}$ and $\mathrm{P}$, being the primary ones used in a language (Lehmann 1986, Fox 1987): Lehmann has subject/absolutive at the top of the hierarchy, followed by direct object/ergative. And according to Fox, languages, if they can relativize at all, must be able to relativize on $\mathrm{S}$ and $\mathrm{P}$-with an absolutive alignment.

What we find in Thulung is that - $p a$ and $-m$ strategies in Thulung are accessing different alignments: the $-m$ strategy follows an absolutive alignment, making it possible to relativize on $S$ and $\mathrm{P}$ (but not A), while the - pastrategy makes it possible to relativize on S and A (but not P).

Another interesting insight from Lehmann 1986 is the idea that prenominal RC's are more likely to be nominalized - the Thulung data certainly supports this: all types of RC's are prenominal, and all are very much nominalized, using either an actual nominalizer $(-m)$ to achieve relativization, or a participial strategy (with all this implies about the nominalization of the clause, in terms of constraints on tense marking). Lehmann shows that "the degree of nominalization of a RC correlates with [...] its achievement on the hierarchy of syntactic functions" (1986: 672): "the more a $\mathrm{RC}$ is nominalized, the less it can systematically make various syntactic functions available for relativization". Yet what we see from Table 2 is that both principal (in other words those accessing S) Thulung relativization strategies, despite being nominalized, do very well in terms of allowing access to multiple positions. Nonetheless, - $m$ indeed fares better than - $p a$, as might be expected insofar as $-m$ is used to relativize a finite clause, which due to its preserved person/tense indexation, can be seen as more verbal (and less nominalized) than the participial clauses resulting from relativization with - $p a$ (which indeed allow less access to positions on the hierarchy, as would be expected.

An issue of great interest with respect to strategies for relativization is Thulung's split system in terms of its case marking: ergative marking occurs on A's that are $2 \mathrm{PL}^{9}$ and 3 person, and the other persons are unmarked when in the A role (see Lahaussois 2003b). Nonetheless, all head nouns, regardless of person/number, and their position with respect to the split case marking system, undergo the restriction on relativization with - $m$ when they are in an A role. Whether or not it takes ergative case marking, no $A$ is accessible for relativization with - $m$. In other words, relativization strategies tap into different alignments from morphological marking of case.

Interestingly, another Kiranti language, Yakkha, has the same distribution of relativization strategies over core arguments: a nominalizer - khuba is used for S and A (and which is the only strategy available for A relativization), and two nominalizers, one singular and the other non-

\footnotetext{
8 "In languages with ergative alignment, it is possible to find situations where the subject of transitive constructions cannot be relativized upon."

9It seems likely that the split was originally between 1, 2 on the one hand and 3 on the other, but shifted 'upwards' based on the influence of Nepali and pressure to create, from the 2PL pronoun, a 2sG polite pronoun form, resulting in the creation of a new plural marked 2PL pronoun.
} 
singular, =na and $=$ ha respectively, used for, among other things, relativization of $\mathrm{S}$ and $\mathrm{P}$ as well as of other core and non-core arguments (including G and T) (Schackow 2015: 407-411). Like Thulung, Yakkha has a split ergative system, whereby 1st and 2nd person are nominative marked when A, and 3rd person is ergative marked when A (Schackow 2015: 129). In other words, we find a very close match between the situations in the two languages, with regards to morphological marking and to relativization strategies, even though closer languages to Yakkha are much freer in the use of nominalizers with respect to grammatical relations (Schackow 2015: 408).

\section{Conclusion}

In this article, I have presented the three relativization strategies available for Thulung. These are a nominalizer - $m$ and two participial markers - $p a$ and - $m a$. All three have different distributions, depending on the argument of the head noun of the relative clause. The two strategies which are used to relativize on $\mathrm{S}$ are - $m$ and - $p a$, but the former cannot be used to relativize on A's, while the latter cannot be used to relativize on P's. Neither of these two strategies therefore can be used on a continuous run of Keenan and Comrie's accessibility hierarchy, yet both tap into different alignments: an absolutive alignment for - $\mathrm{m}$, and an ergative alignment for - $p a$.

An issue of considerable interest was that of the mapping of relativization strategies onto case marking in Thulung. Despite Thulung's having ergative case marking with a person-based split, all persons were treated the same by the available relativizing strategies. Concurrently, it was found that even though Thulung has two types of ditransitive verbs in terms of agreement marking (one type marking $A$ and $T$ on transitive verbs, the other $A$ and $G$ ), the case marking of $G$ and $T$ is the same for both verb classes (a primary object case alignment), with relativization strategies matching this alignment: both $\mathrm{G}$ and $\mathrm{T}$ were accessible to relativization using the same strategies, these in turn matching the strategies for $\mathrm{P}$.

Acknowledgements

I wish to thank the anonymous reviewers for their useful comments. I also wish to thank my Thulung consultants, especially Chandra Kala Rai. This research was funded by the HimalCo project (ANR-12-CORP-0006).

$\begin{array}{ll}\text { Abbreviations } \\ \text { ACT.PASS active participle } \\ \text { CONJ } & \text { conjunction } \\ \text { CONT } & \text { continuative } \\ \text { CONTR } & \text { contrastive } \\ \text { DE } & \text { dual exclusive } \\ \text { DO } & \text { direct object } \\ \text { HS } & \text { hearsay } \\ \text { INT } & \text { intensifier } \\ \text { IO } & \text { indirect object }\end{array}$

\begin{tabular}{|c|c|}
\hline \multicolumn{2}{|c|}{ OBJ COMP } \\
\hline \multirow{2}{*}{$\begin{array}{l}\text { OBJ COMP } \\
\text { ONOM } \\
\text { PASS.PTCP }\end{array}$} & onomatopeion \\
\hline & passive participle \\
\hline PE $\quad p$ & plural exclusive \\
\hline PI & plural inclusive \\
\hline TEMP & temporal \\
\hline$X>Y$ & agent $X$ acting on patient $Y$ \\
\hline
\end{tabular}

\section{References}

Allen N.J. 1975. Sketch of Thulung grammar, with three texts and a glossary. Ithaca: China-Japan Program.

Bickel, Balthasar. 1995. Relatives à antécédent interne, nominalisation et focalisation : entre syntaxe et morphologie en bélharien. Bulletin de la Société Linguistique de Paris 90(1), 391-427. 
Bickel, Balthasar. 1999. Nominalization and focus constructions in some Kiranti languages. In Yadava, Yogendra P. \& Glover , Warren G., (eds.), Topics in Nepalese Linguistics, 271-296.

Kathmandu: Royal Nepal Academy

Bickel, Balthasar, Rai, Manoj, Paudyal, Netra P, Banjade, Goma, Bhatta, Toya Nath, Gaenszle, Martin, Liever, Elena, Rai, Ichcha Purna, Rai, Novel Kishore \& Stoll, Sabine. 2010. The syntax of threeargument verbs in Chintang and Belhare (Southeastern Kiranti). In Malchukov, Andrej, Haspelmath, Martin, Comrie, Bernard (eds), Studies in ditransitive constructions: A comparative handbook, 382408. Berlin: De Gruyter Mouton.

Creissels, Denis. 2006. Syntaxe générale, une introduction typologique. Paris: Hermes Science Publications.

DeLancey, Scott. 1989. Relativization and nominalization in Tibeto-Burman. Ms., University of Oregon.

Dixon, RMW. 2009. Basic linguistic theory. Vol 2.: Grammatical topics. Oxford: Oxford University Press.

Fox, Barbara A. 1987. The noun phrase accessibility hierarchy reinterpreted: Subject primacy or the absolutive hypothesis? Language 63(4). 856-870.

Genetti, Carol. 2011. Nominalization in Tibeto-Burman languages of the Himalayan area: A typological perspective. In Yap et al (2011).

Genetti, Carol, Bartee, Ellen, Coupe, Alec, Hildebrandt, Kristine \& Lin, You-Jing. 2008. Syntactic aspects of nominalization in five Tibeto-Burman languages of the Himalayan area. Linguistics of the Tibeto-Burman Area 31(2). 97-143.

Jacques, Guillaume. To appear. Complementation in Japhug Gyalrong. Linguistics of the TibetoBurman Area.

Jacques, Guillaume \& Lahaussois, Aimée. 2014. The auditory demonstrative in Khaling. Studies in Language 38(2). 393-404.

Keenan, Edward L. \& Comrie, Bernard. 1977. Noun Phrase Accessibility and Universal Grammar. Linguistic Inquiry 8(1). 63-99.

Lahaussois, Aimée. 2003a. Nominalization and its various uses in Thulung Rai. Linguistics of the Tibeto-Burman Area 26:1. 33-57.

Lahaussois, Aimée. 2003b, Ergativity in Thulung Rai: A shift in the position of pronominal split. In Bradley, David, LaPolla, Randy, Michailovsky, Boyd \& Thurgood, Graham (eds), Language variation: Papers on variation and change in the Sinosphere and in the Indosphere in honour of James A. Matisoff, 101-112. Canberra, Australian National University (Pacific Linguistics)

Lahaussois, Aimée. 2011. The Thulung Rai verbal system: an account of verb stem alternation. Cahiers de Linguistique Asie Orientale 40 (2). 189-224.

Lehmann, Christian. 1986. On the typology of relative clauses. Linguistics 24(4).663-680 
Malchukov, Andrej, Haspelmath, Martin, \& Comrie, Bernard. 2010. Ditransitive constructions: a typological overview. In Malchukov, Andrej, Haspelmath, Martin, Comrie, Bernard (eds), Studies in ditransitive constructions: A comparative handbook, 1-64. Berlin: De Gruyter Mouton.

Matisoff, James A. 1972. Lahu nominalization, relativization, and genitivization. In Kimball, John P. (ed.), Syntax and semantics, Vol. 1, 237-257. New York: Academic Press

Noonan, Michael P. 1997. Versatile nominalization. In Bybee, Joan, Haiman, John, \& Thompson, Sandra (eds.), Essays on language function and language type in honor of Talmy Givón, 374 - 94. Amsterdam: Benjamins

Schackow, Diana. 2015. A grammar of Yakkha (Studies in Diversity Linguistics 7). Berlin: Language Science Press.

Tolsma, Gerard. 2006. A Grammar of Kulung. Leiden: Brill.

van Driem, George. 1993. A Grammar of Dumi. Berlin: Mouton de Gruyter.

Whaley, Lindsay, 2010. Syntactic typology. In Song, Jae Jung (ed), The Oxford handbook of linguistic typology, 465-486. Oxford: Oxford University Press.

Yap, Foong Ha, Grunow-Hårsta, Karen \& Wrona, Janick (eds). 2011. Nominalization in Asian languages. Amsterdam/Philadelphia: John Benjamins. 